\title{
Studies on Correlation and Path Coefficient Analysis in Garden Pea (Pisum sativum L.) varieties
}

\author{
T. N. Vijaya Kumar ${ }^{*}$, T. B. Alloli ${ }^{2}$, H. P. Hadimani ${ }^{2}$, P.S. Ajjappalavar ${ }^{3}$, \\ D. Satish ${ }^{2}$, Abdul Kareem ${ }^{3}$ and C. N. Hanchinamani ${ }^{1}$ \\ ${ }^{1}$ K. R. C College of Horticulture, Arabhavi- 591 218, Karnataka, India \\ ${ }^{2}$ College of Horticulture, Bagalkot- 587 104, Karnataka, India \\ ${ }^{3}$ Horticultural Research Station Devihosur- 581 110, Karnataka, India \\ *Corresponding author
}

\begin{tabular}{l} 
Ke y w o r d s \\
$\begin{array}{l}\text { Leguminosae } \\
\text { (Fabaceae) family, } \\
\text { Pisum ravens, field } \\
\text { pea, sweet pea }\end{array}$ \\
\hline Article Info \\
$\begin{array}{l}\text { Accepted: } \\
\text { 04 November } 2019 \\
\text { Available Online: } \\
\text { 10 December } 2019\end{array}$ \\
\hline
\end{tabular}

\section{A B S T R A C T}

The experiment was conducted during November 2018 - March 2019 in the department of Vegetable science to assess the interrelationship among yield and yield-related attributes and their direct and indirect effects on pod yield. The experiment was laid out in a Randomized Complete Block Design (RCBD) at the research block of K. R. C College of Horticulture, Arabhavi (Karnataka). In the present study, pod yield per plant was significantly and positively correlated with plant height, number of leaves per plant, days to first flowering, days to first picking, number of pods per plant, number of pods per axil, pod length, pod width, pod yield per plot, number of seeds per pod, weight of 100 seeds at both phenotypic and genotypic level. Path coefficient analysis revealed that direct positive effect on pod yield per plant was exhibited by plant height, number of pods per plant, pod length and pod yield per plot and these traits shall be consider for direct selection of genotypes for the successful breeding programme.

\section{Introduction}

A member of Leguminosae (Fabaceae) family and the famous plant species in which G.H. Mendel worked out Mendel's Law and Genetic principles. It is the second most important food legume worldwide after
Phaseolus vulgaris (Taran et al., 2005). It is grown mainly as a winter vegetable in the plains of North India and as a summer vegetable in the hills of other states (Thamburaj, 2015). Pea is of Mediterranean origin, and the Near East and Ethiopia are considered as secondary centres of origin 
(Blixt, 1974). Peas are highly nutritive and are rich source of digestible proteins $(7 \%)$ along with carbohydrates and minerals. There are two sub species, namely Pisum arvens known as field pea, which produce coloured flowers and Pisum sativum, the white flowered, horticultural or garden pea also known as sweet pea.

Yield is a very complex character which is determined by several yield contributing components and also influenced by environmental factors (Singh et al., 2019). Estimation of correlation co-efficient among the yield contributing characters is essential to understand the direction of selection. Hence, understanding of the inter-relationship between pod yield and yield influencing characters is vital importance because this would facilitates effective selection for simultaneous improvement in one or more yield characters.

The correlation coefficient would indicate only the relationship of independent variables with the dependent variable without specifying cause and effect (Akinnola, 2012). Using path coefficient analysis, it is possible to resolve the correlations, by subjecting the correlation co-efficient to path analysis for partitioning the correlation values into direct and indirect effect through alternate ways. It has been widely used to identify traits that have significant effect on yield for potential use in selection.

\section{Materials and Methods}

The experiment was carried out at research block of department of Vegetable Science at Kittur Rani Channamma College of Horticulture, Arabhavi, Belagavi district (Karnataka), UHS, Bagalkot during 20182019. The experimental material comprised of twenty genotypes including check, which were collected from different source (Table 1).
The experiment was laid out in Randomized complete block design (RCBD) design with three replications. The treatments or genotypes were randomly assigned in each replication. All the recommended horticultural practices and plant protection measures were followed uniformly from time to time to raise a healthy crop. During study, observations for plant height $(\mathrm{cm})$, number of primary branches per plant, number of leaves per plant, days to first flowering, days to first picking, number of pods per plant, number of axil per plant, pod length $(\mathrm{cm})$, pod width $(\mathrm{cm})$, number of seeds per pod, weight of 100 seeds, pod yield per plant (g), pod yield per plot, T.S.S and protein (Alikhan, 1973) were recorded on five randomly selected plants from each treatment.

Path coefficient analysis suggested by Wright (1921) and Dewey and Lu (1959) was carried out to know direct and indirect effects of the traits on the total yield per plant. Genotypic and phenotypic correlation coefficients were estimated as suggested by Al-Jibourie et al., (1958).

\section{Results and Discussion}

The character association study was conducted in order to know how various characters are correlated with yield and intercorrelated among each other. Character correlations were made at both genotypic and phenotypic levels as shown in table 2. In general, genotypic correlation was higher than phenotypic correlations for most of the characters studied.

This indicates that the phenotypic expression of correlation is reduced due to the influence of environment. These results are similar to the findings of Nawab et al., (2009), Pal and Singh (2012) and Singh et al., (2019). In the present study, pod yield per plant was significantly and positively correlated with plant height, number of leaves per plant, days to first flowering, days to first picking, 
number of pods per plant, number of pods per axil, pod length, pod width, pod yield per plot, number of seeds per pod, weight of 100 seeds at both phenotypic and genotypic level.

Similar observations were made by Kaur et al., (2007), Gupta et al., (2006), Kalloo et al., (2005) for pod length; Gupta et al., (2006), Kumar and Sharma (2006), Pandey et al., (2015), for number of pods per plant; Singh and Singh (2005), Pal and Singh (2012) for plant height; Devi et al., (2010) for days to first picking; Pal and Singh (2012), Sharma et al., (2009) for days to first flowering; Since, these associated characters are in the desirable direction, it indicated that simultaneous selection for these characters would be rewarding in improving the pod yield.

Therefore, knowledge on the inter correlation association of the traits may be considered as the most reliable selections indices for effective improvement in pea.

Among the studied characters, pod yield per plot had highly correlated and followed by plant height, number of pods per plant, number of leaves per plant, pod length with pod yield per plant both at genotypic and phenotypic level.

Table.1 Details of garden pea genotypes used in the experiment

\begin{tabular}{|c|c|c|}
\hline Sl. No. & Genotypes & Source \\
\hline $\mathbf{1}$ & PS-10 & Collection from West Bengal (Cooch behar) \\
\hline $\mathbf{2}$ & NP-20 & Collection from West Bengal (Cooch behar) \\
\hline $\mathbf{3}$ & Goldie & Collection from West Bengal (Cooch behar) \\
\hline $\mathbf{4}$ & Taj C3 & Collection from West Bengal (Cooch behar) \\
\hline $\mathbf{5}$ & KSP-110 & Collection from West Bengal (Cooch behar) \\
\hline $\mathbf{6}$ & PAN 4009 & Collection from West Bengal (Alipurduar) \\
\hline $\mathbf{7}$ & GS-10 & Collection from Madhya Pradesh (Jabalpur) \\
\hline $\mathbf{8}$ & Super arkel & Collection from Madhya Pradesh(Jabalpur) \\
\hline $\mathbf{9}$ & Jindal-10 & Collection from Madhya Pradesh (Mandsaur) \\
\hline $\mathbf{1 0}$ & VBL-10 & Collection from Maharashtra (Sangli) \\
\hline $\mathbf{1 1}$ & HUB-1 & Collection from Belagavi \\
\hline $\mathbf{1 2}$ & HUB-2 & Collection from Belagavi \\
\hline $\mathbf{1 3}$ & Punjab-89 & Collection from Madhya Pradesh (Mandsaur) \\
\hline $\mathbf{1 4}$ & HUB-3 & Collection from Belagavi \\
\hline $\mathbf{1 5}$ & HUB-4 & Collection from Maharashtra (Kollapur) \\
\hline $\mathbf{1 6}$ & HUB-5 & Collection from Maharashtra (Kollapur) \\
\hline $\mathbf{1 7}$ & HUB-6 & Collection from Belagavi \\
\hline $\mathbf{1 8}$ & HUB-7 & Collection from Bidar \\
\hline $\mathbf{1 9}$ & HUB-8 & Collection from Bidar \\
\hline $\mathbf{2 0}$ & Arka Priya & IIHR, Hesaragatta \\
\hline
\end{tabular}


Table.2.Genotypic and phenotypic correlation coefficients among growth, yield and quality parameters in garden pea genotypes

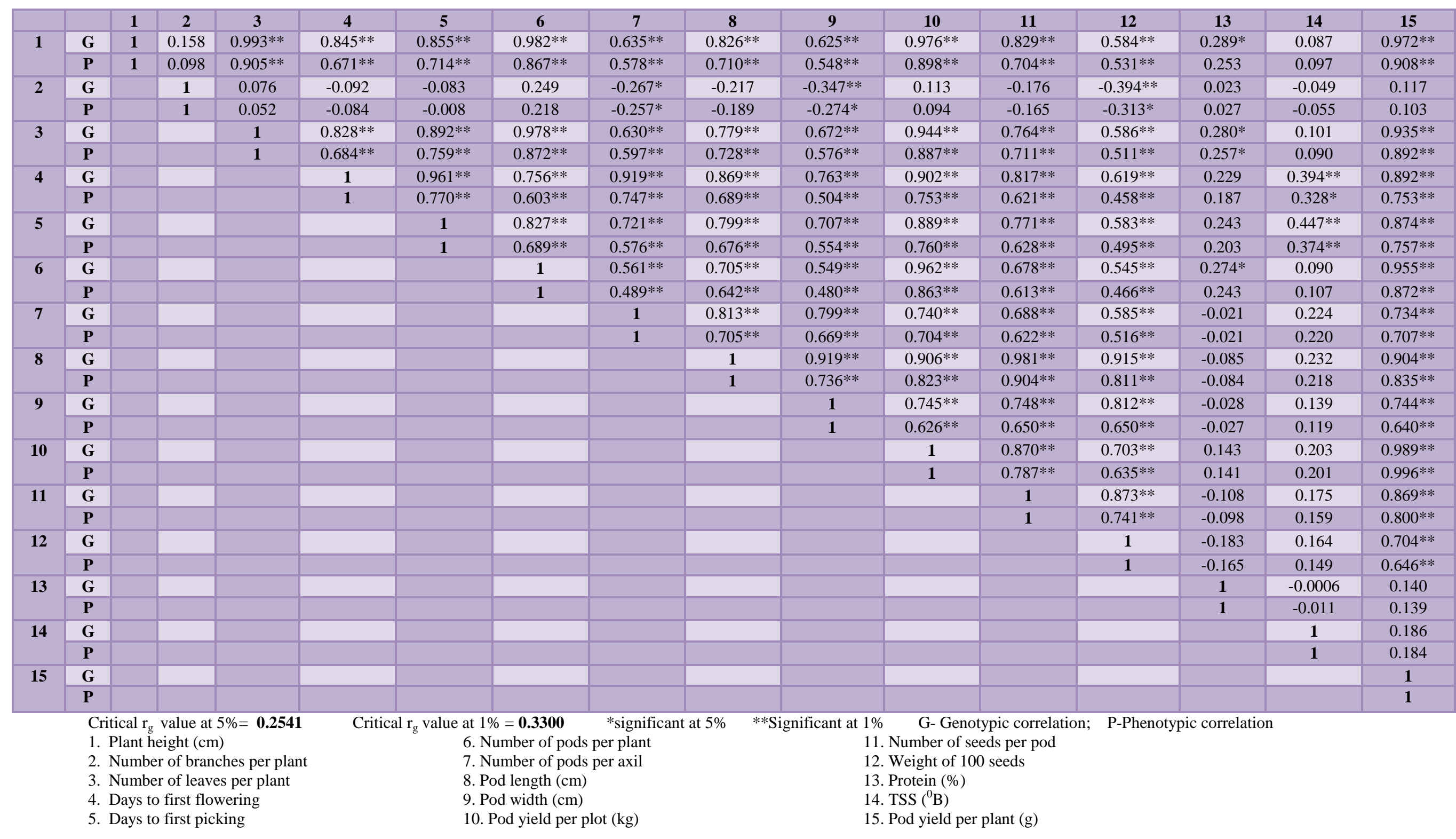


Table.3 Genotypic path coefficient analysis for pod yield and its components in garden pea genotypes

\begin{tabular}{|c|c|c|c|c|c|c|c|c|c|c|c|c|c|c|c|}
\hline & 1 & 2 & 3 & 4 & 5 & 6 & 7 & 8 & 9 & 10 & 11 & 12 & 13 & 14 & rG \\
\hline 1 & 0.0453 & -0.0149 & -0.3965 & -0.0987 & 0.0686 & 0.1339 & -0.0442 & 0.1237 & 0.0199 & 1.2593 & -0.0175 & -0.1044 & 0.0009 & -0.0032 & $0.972 * *$ \\
\hline 2 & 0.0072 & -0.0942 & -0.0305 & 0.0108 & -0.0067 & 0.0340 & 0.0186 & -0.0326 & -0.0110 & 0.1460 & 0.0037 & 0.0704 & 0.0001 & 0.0018 & 0.117 \\
\hline 3 & 0.0451 & -0.0072 & -0.3990 & -0.0967 & 0.0716 & 0.1334 & -0.0438 & 0.1167 & 0.0214 & 1.2183 & -0.0162 & -0.1048 & 0.0008 & -0.0037 & $0.935^{* *}$ \\
\hline 4 & 0.0383 & 0.0087 & -0.3305 & -0.1168 & 0.0771 & 0.1032 & -0.0640 & 0.1301 & 0.0243 & 1.1642 & -0.0173 & -0.1107 & 0.0007 & -0.0145 & $0.892 * *$ \\
\hline 5 & 0.0388 & 0.0079 & -0.3561 & -0.1123 & 0.0802 & 0.1128 & -0.0502 & 0.1197 & 0.0225 & 1.1479 & -0.0163 & -0.1043 & 0.0007 & -0.0165 & $0.874 * *$ \\
\hline 6 & 0.0445 & -0.0235 & -0.3905 & -0.0884 & 0.0663 & 0.1363 & -0.0391 & 0.1056 & 0.0175 & 1.2412 & -0.0143 & -0.0974 & 0.0008 & -0.0033 & $0.955^{* *}$ \\
\hline 7 & 0.0288 & 0.0252 & -0.2514 & -0.1074 & 0.0579 & 0.0765 & -0.0696 & 0.1218 & 0.0254 & 0.9549 & -0.0146 & -0.1047 & -0.0001 & -0.0083 & $0.734 * *$ \\
\hline 8 & 0.0374 & 0.0205 & -0.3110 & -0.1015 & 0.0641 & 0.0962 & -0.0566 & 0.1497 & 0.0292 & 1.1694 & -0.0207 & -0.1637 & -0.0003 & -0.0086 & $0.904 * *$ \\
\hline 9 & 0.0284 & 0.0327 & -0.2682 & -0.0892 & 0.0567 & 0.0749 & -0.0556 & 0.1376 & 0.0318 & 0.9617 & -0.0158 & -0.1452 & -0.0001 & -0.0051 & $0.744 * *$ \\
\hline 10 & 0.0443 & -0.0107 & -0.3768 & -0.1054 & 0.0713 & 0.1312 & -0.0515 & 0.1357 & 0.0237 & 1.2900 & -0.0184 & -0.1257 & 0.0004 & -0.0075 & $0.989 * *$ \\
\hline 11 & 0.0376 & 0.0166 & -0.3049 & -0.0955 & 0.0618 & 0.0925 & -0.0479 & 0.1469 & 0.0238 & 1.1228 & -0.0211 & -0.1560 & -0.0003 & -0.0065 & $0.869^{* *}$ \\
\hline 12 & 0.0265 & 0.0371 & -0.2341 & -0.0724 & 0.0468 & 0.0744 & -0.0408 & 0.1372 & 0.0258 & 0.9078 & -0.0185 & -0.1787 & -0.0006 & -0.0061 & $0.704 * *$ \\
\hline 13 & 0.0131 & -0.0022 & -0.1119 & -0.0267 & 0.0195 & 0.0374 & 0.0015 & -0.0129 & -0.0009 & 0.1854 & 0.0023 & 0.0327 & 0.0030 & 0.0000 & 0.140 \\
\hline 14 & 0.0040 & 0.0047 & -0.0405 & -0.0461 & 0.0359 & 0.0123 & -0.0156 & 0.0348 & 0.0044 & 0.2626 & -0.0037 & -0.0294 & 0.0000 & -0.0369 & 0.186 \\
\hline
\end{tabular}

Diagonal indicates direct effect $\quad *$ Significant at 5\% **Significant at 1\% $\quad$ rG- Genotypic correlation with pod yield per plant 
Table.4 Phenotypic path coefficient analysis for pod yield and its components in garden pea genotypes

\begin{tabular}{|c|c|c|c|c|c|c|c|c|c|c|c|c|c|c|c|}
\hline & 1 & 2 & 3 & 4 & 5 & 6 & 7 & 8 & 9 & 10 & 11 & 12 & 13 & 14 & $\mathbf{r G}$ \\
\hline 1 & 0.0589 & 0.0046 & -0.0034 & 0.0080 & -0.0116 & 0.0387 & 0.0194 & 0.0276 & 0.0086 & 0.7189 & 0.0226 & 0.0140 & 0.0034 & -0.0009 & $0.908 * *$ \\
\hline 2 & 0.0058 & 0.0464 & -0.0002 & -0.0010 & 0.0001 & 0.0098 & -0.0086 & -0.0074 & -0.0043 & 0.0757 & -0.0053 & -0.0083 & 0.0004 & 0.0005 & 0.103 \\
\hline 3 & 0.0533 & 0.0024 & -0.0038 & 0.0081 & -0.0123 & 0.0389 & 0.0200 & 0.0282 & 0.0091 & 0.7094 & 0.0228 & 0.0135 & 0.0035 & -0.0008 & $0.892 * *$ \\
\hline 4 & 0.0395 & -0.0039 & -0.0026 & 0.0119 & -0.0125 & 0.0269 & 0.0250 & 0.0267 & 0.0079 & 0.6026 & 0.0199 & 0.0121 & 0.0025 & -0.0029 & $0.753 * *$ \\
\hline 5 & 0.0420 & -0.0004 & -0.0029 & 0.0092 & -0.0162 & 0.0307 & 0.0193 & 0.0262 & 0.0087 & 0.6084 & 0.0201 & 0.0131 & 0.0027 & -0.0033 & $0.757 * *$ \\
\hline 6 & 0.0510 & 0.0102 & -0.0033 & 0.0072 & -0.0112 & 0.0446 & 0.0164 & 0.0249 & 0.0075 & 0.6908 & 0.0196 & 0.0123 & 0.0033 & -0.0009 & $0.872 * *$ \\
\hline 7 & 0.0341 & -0.0120 & -0.0023 & 0.0089 & -0.0093 & 0.0218 & $\mathbf{0 . 0 3 3 5}$ & 0.0274 & 0.0105 & 0.5636 & 0.0199 & 0.0136 & -0.0003 & -0.0019 & $0.707 * *$ \\
\hline 8 & 0.0418 & -0.0088 & -0.0028 & 0.0082 & -0.0109 & 0.0286 & 0.0236 & 0.0388 & 0.0116 & 0.6582 & 0.0290 & 0.0214 & -0.0011 & -0.0019 & $0.835^{* *}$ \\
\hline 9 & 0.0323 & -0.0127 & -0.0022 & 0.0060 & -0.0090 & 0.0214 & 0.0224 & 0.0285 & 0.0157 & 0.5012 & 0.0208 & 0.0171 & -0.0004 & -0.0010 & $0.640 * *$ \\
\hline 10 & 0.0529 & 0.0044 & -0.0034 & 0.0089 & -0.0123 & 0.0385 & 0.0236 & 0.0319 & 0.0098 & 0.7998 & 0.0252 & 0.0168 & 0.0019 & -0.0018 & $0.996 * *$ \\
\hline 11 & 0.0415 & -0.0077 & -0.0027 & 0.0074 & -0.0102 & 0.0273 & 0.0208 & 0.0351 & 0.0102 & 0.6295 & 0.0320 & 0.0196 & -0.0013 & -0.0014 & $0.800 * *$ \\
\hline 12 & 0.0313 & -0.0146 & -0.0019 & 0.0054 & -0.0080 & 0.0208 & 0.0173 & 0.0315 & 0.0102 & 0.5080 & 0.0238 & 0.0264 & -0.0022 & -0.0013 & $0.646^{* *}$ \\
\hline 13 & 0.0149 & 0.0013 & -0.0010 & 0.0022 & -0.0033 & 0.0109 & -0.0007 & -0.0033 & -0.0004 & 0.1132 & -0.0031 & -0.0044 & 0.0135 & 0.0001 & 0.139 \\
\hline 14 & 0.0057 & -0.0026 & -0.0003 & 0.0039 & -0.0061 & 0.0048 & 0.0074 & 0.0085 & 0.0019 & 0.1612 & 0.0051 & 0.0039 & -0.0002 & -0.0088 & 0.184 \\
\hline
\end{tabular}

Diagonal indicates direct effect $\quad *$ Significant at $5 \% \quad * *$ Significant at $1 \%$ rG- Genotypic correlation with pod yield per plant 
The study of correlation alone when considered on the criteria for selection for high yield would be misleading. In addition, knowledge on presence of association among component characters reveals that some of them may serve as indicator of yield.

This involves partitioning of the correlations into direct and indirect effects via alternative characters or pathways. Since a character may not be directly correlated with yield but may feature depend in other characters, by path analysis it is possible to find out the direct and indirect influence of component characters on the yield. Path analysis were made at both genotypic and phenotypic levels as shown in table 3 and 4.

The residual effect of path coefficient analysis was 0.0589 for pod yield per plant at genotypic and phenotypic levels.

Significant positive direct effect on pod yield per plant was observed by Plant height, days to first picking, number of pods per plant, pod length, pod width and pod yield per plot at genotypic level. Whereas, Significant and positive direct effect on pod yield per plant was also recorded by plant height, number of branches per plant, days to first flowering, number of pods per plant, number of pods per axil, pod length, pod width, pod yield per plot, number of seeds per pod, weight of 100 seeds and protein. Similar observations were reported by Nawab et al., (2008), Katoch et al., (2016), Katiyar et al., (2014) for number of pods plant, number of seeds per pod; Singh et al., (2011), Sharma et al., (2007) for plant height, number of branches per plant, pod length; Singh and Mishra (2008) for weight of 100 seeds; in their experiments.

Based on the results obtained, the characters like plant height, number of leaves per plant, number of pods per plant, pod length, pod yield per plot were the important pod yield attributes.
Among these, pod yield per plot, plant height and number of pods per plant were highly positive and significantly correlated with pod yield per plant and also showed direct effect on pod yield per plant. Hence, these traits have to be considered while selecting for pod yield per plant.

\section{References}

Akinnola A. 2012, Path analysis step by step using excel. Journal of Technical Science and Technologies., 1(1): 9-15.

Ali-khan, S. T. and Youngs, C. G., 1973, Variation in protein content in field pea. Can. J. Plant Sci., 53: 37-41.

Al-Jibouri, H. A., Miller, P. A. and Robinson, H. V., 1958, Genotypic and environmental variances in an upland cotton cross of inter specific origin. Agron. J., 50: 633636.

Blixt, S., 1974, The pea, Hand book of genetics, Plenum Press, New York., 2: p p.181221.

Devi, P. O., Pant, S. C., Rawat, S. S., Rana, D. K. and Singh, N. K., 2010, Correlation coefficient and genetic divergence analysis in pea. Indian Journal of Horticulture., 67: 160-165.

Dewey, D. R. and Lu, K. N., 1959, Correlation and path coefficient analysis of components of crested wheat grass seed production. Agron. J., 51: 515-518.

Gupta, A. J., Singh, Y. V. and Verma, T. S., 2006, Genetic variability and heritability in garden pea (Pisum sativum L.). Indian J. Horti., 63 (3): 332-334.

Kalloo, G., Rai, M., Singh, J., Verma, A., Kumar, R. and Rai, G. K., 2005, Morphological and biochemical variability in vegetable pea (Pisum sativum L). Vegetable Science., 32: 1923.

Katiyar, S. K., Singh, H. C., Gangwar, R. S., Verma, M. C. and Singh, R. K., 2014, Genetic variability and selection parameters in pea (Pisum sativum L.). Bioscience., 7 (9): 720-723. 
Katoch, V., Singh, P., Devi, M. B., Sharma, A., Sharma, G. D. and Sharma, J. K., 2016, Study of genetic variability, character association, path analysis and selection parameters for heterotic recombinant inbred lines of garden peas (Pisum sativum var. hortense L.) under mid-hill conditions of Himachal Pradesh, India. Legume Research., 39 (2): 163-169.

Kaur, H., Singh, M. and Brar, P. S., 2007, Correlation and path analysis in garden pea (Pisum sativum L.). Crop Improvement., 34 (2): 186-188.

Kumar, V. R. and Sharma, R. R., 2006, Character association studies in garden pea. Indian. J. Horti., 63 (2): 185-187.

Nawab, N. N., Subhani, G. M., Qamar, K. M. and Saeed, S. A., 2008, Genetic variability, correlation and path analysis studies in garden pea (Pisum sativum L.). Journal of Agricultural Research., 46 (4): 333-340.

Pal, A. K. and Singh, S., 2012, Assessment and genetic variability in garden pea (Pisum sativum L. var. hortense). International Journal of Agricultural Sciences., 7 (2): 569-573.

Pandey, P., Singh, N. and Rawat, M., 2015, Study of genetic variation, heritability and correlation in vegetable pea (Pisum Sativum L.). The Bioscan., 10 (4): 21312133.

Sharma, A., Sood, M., Rena, A. and Singh, Y., 2007, Genetic variability and association studies for pod yield and component horticultural traits in garden pea under high hill dry temperate conditions. Indian Journal of Horticulture., 64 (4): 410-414.
Sharma, M. K., Chandel, A. and Kohli, U. K., 2009, Genetic evaluation, correlations and path analysis in garden pea (Pisum sativum var. hortense L.). Annals of Horticulture., 2 (1): 33-38.

Singh, A., Singh, S. and Babu, J. D. P., 2011, Heritability, character association and path analysis studies in early segregating population of field pea (Pisum sativum L. var. arvense). International Journal of plant breeding and genetics., 5 (1): 8692.

Singh, D. and Mishra, V. K., 2008, Studies on genetic divergence in pea (Pisum sativum L.). Agricultural Science Digest., 28 (1): 77-78.

Singh, J. D. and Singh, I. P., 2005, Genetic variability, heritability, expected genetic advance and character association in field pea (Pisum sativum L.). Legume Research., 29 (1): 65-67.

Singh, S., Singh, B., Sharma, R., Verma, V. and Kumar, M., 2019, Character association and path analysis in diverse genotypes of pea (Pisum sativum L.). Int. J. Curr. Microbiol. App. Sci., 8 (2): 706-713.

Taran, B., Zhang, C., Warkentin, T., Tullu, A. and Vanderberg, A., 2005, Genetic diversity among varieties and wild species accessions of pea (Pisum sativum $\mathrm{L}$.) based on molecular markers, morphological and physiological characters. Genome., 48 (2): 257.

Thamburaj, S. and Singh, N., 2015, Text book of vegetables, tuber crops and spices. ICAR, New Delhi. pp.196-200.

Wright, S., 1921, Correlation and causation. $J$. Agric. Res., 20: 557-585.

\section{How to cite this article:}

Vijaya Kumar, T. N., T. B. Alloli, H. P. Hadimani, P. S. Ajjappalavar, D. Satish, Abdul Kareem and Hanchinamani, C. N. 2019. Studies on Correlation and Path Coefficient Analysis in Garden Pea (Pisum sativum L.) varieties. Int.J.Curr.Microbiol.App.Sci. 8(12): 3024-3031. doi: https://doi.org/10.20546/ijcmas.2019.812.352 